\title{
Impact of Government Agricultural Input Subsidy Card on Rice Productivity in Rajbari District of Bangladesh: Application of Endogenous Switching Regression Model
}

\author{
P. K. Sarma ${ }^{1, *}$, M. M. Rahman ${ }^{2}$ \\ ${ }^{1}$ Senior Scientific Officer, Bangladesh Agricultural University Research System (BAURES), Bangladesh Agricultural University, \\ Mymensingh-2202, Bangladesh \\ ${ }^{2}$ Establishment Department, Section-3, Bangladesh Agricultural University, Bangladesh
}

Received June 6, 2020; Revised July 16, 2020; Accepted August 10, 2020

\section{Cite This Paper in the following Citation Styles}

(a): [1] P. K. Sarma, M. M. Rahman, "Impact of Government Agricultural Input Subsidy Card on Rice Productivity in Rajbari District of Bangladesh: Application of Endogenous Switching Regression Model," Universal Journal of Agricultural Research, Vol. 8, No. 5, pp. 131 - 145, 2020. DOI: 10.13189/ujar.2020.080501.

(b): P. K. Sarma, M. M. Rahman (2020). Impact of Government Agricultural Input Subsidy Card on Rice Productivity in Rajbari District of Bangladesh: Application of Endogenous Switching Regression Model. Universal Journal of Agricultural Research, 8(5), 131 - 145. DOI: 10.13189/ujar.2020.080501.

Copyright $₫ 2020$ by authors, all rights reserved. Authors agree that this article remains permanently open access under the terms of the Creative Commons Attribution License 4.0 International License

\begin{abstract}
This paper aims to use a novel version of an endogenous switching regression model to examine the impact of agricultural input subsidy assistance card on-farm productivity in Bangladesh. A multistage random sampling technique was employed to select a total of 400 farm households including 181 (45.25\%) adaptors and 219 (54.75\%) non-adaptors and interviewed by using pre-canvassing structured survey questionnaires. Also, FGDs and KIIs have been conducted to get qualitative information. The descriptive statistics, probit regression-double hurdle model, endogenous switching regression (ESR) technique, and propensity score matching approach were used to analyze the collected data. The ESR model supported by binary and PSM was used to empirically assess the impact of subsidy card adaptors on outcome variables. The results revealed significant production enhancing effects of agricultural input subsidy on-farm production and farm income in Bangladesh only under the assistance of input subsidy card. The findings also showed higher production and incomes for those participating in the program. However, a comprehensive input subsidy assistance card package is certainly a requirement for increasing production and income. As the adoption of input subsidy assistance card seems to enhance farm productivity, the study recommends increased coverage of the subsidy program, extension advocacy and
\end{abstract}

opening up to ensure agricultural productivity and increased farm incomes. This study illustrates how agricultural input subsidy assistance cards can improve farm production and income in Bangladesh.

Keywords Inputs Subsidy, Impact, Farm Production, Farm Income, Bangladesh

\section{Introduction}

Agriculture sector in Bangladesh contributes around $16 \%$ of the country's GDP and employs $45 \%$ labour force. It has a pressure of feeding 156.6 million populations. The majority of the farmers in Bangladesh are smallholders; almost $70 \%$ farmers own less than 0.4 hectares of land. Around $45 \%$ households are poor and 53\% are landless who depend on agriculture for employment. It plays an important role in economic growth, enhancing food security and poverty reduction in most developing countries like Bangladesh (Dalango et al., 2019). Agriculture contributes a significant portion of most developing countries gross domestic product, informal employment, food and farm incomes for more than half of the rural population (Dorward et al.,2010).Therefore, it is 
assumed that by increasing the production per unit land and with access to ready markets, rural populations could experience less hunger and high incomes (Chirwa and Dorward, 2013). However, agricultural inputs are a great determinant of yields in any type of agricultural production. Nevertheless, smallholder farmers face high input price and low adoption of new technology and low producer prices for enhancing incomes due to the bureaucracy in procuring formal inputs that demands collateral, high-interest rates, and the risk-averse behavior by agricultural farmers to demand inputs considering the risk associated with failure to repay. Countries that depend on agriculture or that protect infant agricultural sectors use some form of subsidy to cushion farmers against high prices and to increase farm outputs. However, subsidies may negatively affect productivity when they distort the production structure which leads to allocate inefficiency through investment in subsidy-seeking activities that are relatively less productive (Alston and James, 2002). In the context of the WTO agenda, agricultural subsidy harms agricultural markets. To avoid the negative effect of coupled subsidies, governments of many countries have shifted from coupled to decoupled subsidies that are independent of farm production and input use decision (Rizov et.al,,2013).The sustainable agricultural development necessary for economic transformation comes from expanded input use, especially of modern inputs i.e seed, fertilizers, pesticides and agro-chemicals, machinery, and irrigation that embodies improved technologies (Sheahan et al., 2017). To ensure food security and safety, Bangladesh government introduces an "Agriculture Input Subsidy Assistance Card (ISAC) Programme” for marginal (0.02-0.19 ha), small (0.20-1.00 ha) and medium (1.01-3.03 ha) farmers to get cash subsidies. The new system would conduct smooth cash transfers and reduce the misappropriation of financial support. It is to make the best use of all facilities sponsored by the government. The cash subsidies are given through the input assistance card to the farmers. About a total of 1.82 crore farmers of the country will be covered in the program (Unnayan Onneshan 2019). Farmers got incentives from banks by using the ISAC to buy diesel or any other input. For withdrawn a subsidy incentive and monetary transactions, the farmers have to open bank accounts for only Tk 10 . The ISAC was considered as the final identity of farmers to access government subsidy.

\section{Objectives of the Study}

The objective of the study was to identify the influencing factors of smallholder farmers' participation decision of the current government input subsidy assistance card and its impact on farm production of rice and income in Bangladesh. The specific objectives of this study are:
1) To identify the influencing factors that determine the access to government agriculture input assistance card of the sample farmers.

2) To measure the impact of the current government agricultural input assistance cards strategies on production and income of the sample farmers; and.

3) To compare farm production and income between treatment and control groups of input subsidy card in the study area.

The following hypothesizes are tested:

1) There is no connection between government input subsidy assistance card and on-farm production.

2) There is no relationship between government input subsidy assistance card participation and income.

The findings of the investigation will go far to contribute to increasing crop production and farmer's income. It will also contribute to whether government input subsidy assistance card is a feasible technique in creating smallholder farmers' crop production and income in Bangladesh as well as in developing countries.

\section{Conceptual Framework}

An analysis of the effect of farm level inputs requires an understanding of the relationship between inputs and agricultural production. It is also important to understand how external factors can affect this relationship. The government intervention in incomplete through the provision of subsidized inputs requires that the program should be well designed in terms of target farmers and its implementation. Good institutions and policies together with subsidy design will enable the programme to achieve its target group and objectives. Policy analysts argue that government intervention through the provision of subsidized inputs eannot to accomplish the expected outcome because it often misses its objectives (Buttari, 1995, Dorward et al., 2008). It is assumed that inputs subsidy will help financially constrained farmers to acquire more yield-enhancing inputs. The assumption is that programme providing subsidized inputs will enable farmers who cannot afford formal inputs to increase their disposable income which in turn will be used to acquire more agricultural inputs and technology. It can be express the following ways

$U_{i}=X^{\prime} \beta_{i}+\varepsilon_{i}$ and $U_{k}=X^{\prime} \beta_{i k}+\varepsilon_{k}$ then if $\mathrm{Y}=1$ the decision makers' choice of alternative it is given by;

$$
\left.\begin{array}{rl}
\operatorname{Pr} o b[Y & =1 \mid x]=\operatorname{Pr} o b\left[U_{i}>U_{k}\right] \\
& \left.=\operatorname{Pr} o b\left[x^{\prime} \beta_{i}+\varepsilon_{i}-x^{\prime} \beta_{k}-\varepsilon_{k}>0 \mid x\right]\right] \\
& \left.=\operatorname{Pr} o b\left[x^{\prime}\left(\beta_{i}-\beta_{k}\right)+\varepsilon_{i}-\varepsilon_{k}>0 \mid x\right]\right] \\
& =\operatorname{Pr} o b\left[x^{\prime} \beta+\varepsilon>0 \mid x\right]
\end{array}\right\}
$$


Incremental use of inputs and changes in production patterns as a result of input use is intermediate outcomes. Besides inputs, household characteristics such as education, gender, age, experience have an influence on intermediate outcomes. Changes in productivity occur once the intermediate outcomes are satisfied. The structure of output market, distance to both input and output markets, infrastructures and contacts with extension service providers also influence production and income. Indirect effects such as consumer welfare and economic growth may be affected by changes in agricultural products' prices and the use of agricultural inputs.

\section{Materials and Methods}

This section describes the study area, sampling method and the instruments of data collection applied. It presents the specification of the empirical model and tools of data analysis and interpretation.

Study area: The study was conducted in 5 (five) Upazilas namely Pangsha, Kalukhali and Baliakandi under Rajbari district of Bangladesh because of their crop production potential.

Sampling strategy and sample frame: The multi-stage sampling procedure was employed to obtain cross-sectional data from 400 samples by using predetermined survey schedule. First, the five upazilas were purposively selected based on their crop production hinterland. First, purposive sampling method was applied to select Rajbari district because it is one of the largest agricultural producers in the country. Then farmers were randomly selected and a short-structured questionnaire was administered to each farmer to obtain cross-sectional data.

The samples for this study distinguished according to the formula for sample size determination for finite population given by Kothari (2004) as shown below:

$$
n=\frac{Z^{2} p \cdot q \cdot N}{e^{2}(N-1)+Z^{2} \cdot p \cdot q}
$$

Where:

$\mathrm{n}=$ stands for estimated sample size,

$\mathrm{e}=$ the allowable error; $(0.05)$

$\mathrm{N}$ = number of population under the study (150892);

$\mathrm{p}=$ sample proportion of successes $(\mathrm{P}=0.5)$;

$\mathrm{q}=1-\mathrm{p}(1-0.5=0.5)$

$\mathrm{z}=$ standard vitiate for given $95.5 \%$ confidence level $(\mathrm{Z}=1.96)$

Researcher (s) can have the following:-

$$
\begin{gathered}
n=\frac{(1.96)^{2} \times(0.5) \times(0.5) \times 150892}{(0.05)^{2} \times(150892-1)+(1.96)^{2} \times(0.5) \times(0.5)} \\
=\frac{144916.6768}{378.1879}=383
\end{gathered}
$$

Hence, 383 respondents rounded off to 400 to enable the distribution of the sample in 5 (five) selected Upazilas (Table 1). Based on the size of farm households in each

\begin{tabular}{|c|c|c|c|c|}
\hline \multirow{2}{*}{ Selected Upazilas } & \multirow{2}{*}{$\begin{array}{l}\text { Total No. of farm } \\
\text { household }\end{array}$} & \multicolumn{2}{|c|}{ No. of farm household in Village } & \multirow[t]{2}{*}{ Sampled responden } \\
\hline & & Selected Villages & Total & \\
\hline \multirow{2}{*}{ Pangsha } & \multirow{2}{*}{54116} & Ambaria & 40 & \multirow{2}{*}{80} \\
\hline & & Komorpur & 40 & \\
\hline \multirow{2}{*}{ Baliakandi } & \multirow{2}{*}{28353} & Boalia & 40 & \multirow{2}{*}{80} \\
\hline & & Majhbari & 40 & \\
\hline \multirow{2}{*}{ Kalukhali } & \multirow{2}{*}{21045} & Nawabpur & 40 & \multirow{2}{*}{80} \\
\hline & & Narua & 40 & \\
\hline \multirow{2}{*}{ Goalanda } & \multirow{2}{*}{10637} & Debagram & 40 & \multirow{2}{*}{80} \\
\hline & & Ujan Char & 40 & \\
\hline \multirow{2}{*}{ Rajbari Sadar } & \multirow{2}{*}{36741} & Raynagor & 40 & \multirow{2}{*}{80} \\
\hline & & Chondoni & 40 & \\
\hline Total 5 Upzalas & 150892 & 10 Villages & 400 & 400 \\
\hline
\end{tabular}
Upazila, these 80 potential respondents were designated.

Table 1. The list of selected rice producing areas and sample size in each study site

Source: Filed Survey data 2020 


\section{Analytical framework}

In this paper, researchers used combinations of analytical tools to ensure robustness of empirical results. To determine the factors affecting the adoption of the government subsidy assistance card, a binary probit regression model was used. Keeping in view the disguised endogeneity, the ESR model and propensity score matching method were used to examine the impact of subsidy assistance card adoption on farm production and income. These two methods are systematically briefly discussed below.

Estimation of switching regression model: In impact studies using non-experimental or quasi-experimental designs, different approaches can be applied but there are three widely used models, namely propensity score matching, 2 stages least squares, and switching regression models. Hennessy (1998) and Ciaian and Swinnen (2009) analyzed the use of two least squares to assess the impact of inputs subsidies on productivity concluded that the disadvantage of such approach is that it does not explicitly incorporate subsidies into a structural estimation algorithm and thus it cannot capture their true effect on productivity. It is also argued that this approach does not take into account self-selection problems that can provide biased estimates, therefore propensity score matching and endogenous models could be used to correct these shortcomings. Econometric problem involving both heterogeneity and sample selection motivates the use of endogenous switching regression model (Maddala, 1983). This study applied a switching regression model to control for self-selection problems and heterogeneity. To compare the estimates, propensity score matching was also used to compute the average treatment effect on the treated (ATT). To account for selection bias from both observable and unobservable factors, we employ the ESR. It (Duso 2005; Hermes and Lensink 2007)) is a parametric approach that uses two different estimation equations for the participant and non-participant women by adding the inverse mills ratio, controlling for selection bias. Inverse mills ratio is calculated through a selection equation in the first step where the selective sample is treated as a missing value problem. Then for each regime conditioned on the adoption decision, the outcome equations are disposed of differently, which are estimated by a probit model.

Endogenous switching regression model: Various literature shows that many impacts based on cross-sectional data have moved towards endogenously switching regression model (Alene and Manyong, 2007; Amare et al., 2012; Asfaw et al., 2012; Kassie et al., 2015; Abdulai and Huffman 2014). The matching strategies only control for heterogeneity effects due to observable covariates. The endogenous switching regression techniques to control for selection bias and unobserved heterogeneity (Loksin and Sajaia 2004; Malikov and Kumbhakar 2014). This model is comprised of the selection equation or the criterion function and two continuous regressions that describes the behaviour of the farmer as he faces the two regimes of adopting the improved fallows or not. To correct this, endogenous switching regression analysis was used and selectivity was modeled using a Probit model. The selection equation is assuming that the farmer aims to maximize utility, comparing utility provided by alternatives, then the condition for farmer $\mathrm{i}$ to select option $\mathrm{j}$ over any other in $m$ is that $Y_{i j}>Y_{i m} m \neq j$.

$$
Y_{i j}=X_{i} \beta_{j}+\varepsilon_{i}
$$

The outcome $Y_{i j}$ which the farmer acquires from the use of subsidized loan $j$, is a latent variable determined by observed farmers' characteristics $\left(X_{i j}\right)$ and unobserved characteristics $\left(\varepsilon_{i j}\right)$

The outcome $Y_{i j}$ which the farmer acquires from the use of subsidized loan $j$, is a latent variable determined by observed farmers' characteristics $\left(\mathrm{X}_{i j}\right)$ and unobserved characteristics $\left(\varepsilon_{i j}\right)$. Equation (iii) will test whether productivity depends on whether or not the farmer used inputs subsidy. If the farmer used inputs subsidy (participation =1), then the farmer enters regime 1 where productivity is more likely; if the farmer did not use inputs subsidy (participation $=0$ ) then he remains in a state less conducive to productivity.

Self-selection models: The following model describes the behaviour of the farmer with two regression equations and a criterion function or treatment ${ }_{i}$ which determines which regime the farmer faces (inputs market participant/non participant)

$$
\left.\begin{array}{l}
T_{i}=1 \text { if } \gamma Z_{i}+u_{i}>0 \\
T_{i}=0 \text { if } \gamma Z_{i}+u_{i} \leq 0
\end{array}\right\}
$$

The following Lokshin and Sajaia (2011), the binary outcomes conditional on access to government input subsidy assistance card use are specified as an endogenous switching regime model;

$$
\left.\begin{array}{l}
\text { Regime } 1: y_{1 i}=X_{1 i} \beta_{1}+\varepsilon_{1 i} \text { if } T_{i}=1 \\
\text { Regime } 0: y_{0 i}=X_{1 i} \beta_{0}+\varepsilon_{0 i} \text { if } T_{i}=0
\end{array}\right\}
$$

Where, $y_{1 i}$ is the dependents variable (farm productivity): $X_{0 i}$ and $X_{1 i}$ are vectors of exogenous variables, and $\beta_{0}, \beta_{1}$ and $y$ are vectors of parameters. Assuming that $u_{i}, \varepsilon_{1}$ and $\varepsilon_{0}$ are normally distributed with a mean vector zero and covariance matrix.

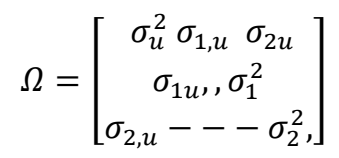

$\sigma_{u}^{2}$ is the variance of error term in the selection equation, $\sigma_{1}^{2}$ and $\sigma_{2}^{2}$ and are variance of the error terms in the continuous equations. $\sigma_{1, u}$ is a covariance of $u_{0}$ and $\varepsilon_{0}$ and $\sigma_{2 u}$ is a covariance of $u_{1}$ and $\varepsilon_{1}$. Since $y_{1 i}$ and $y_{0 i}$ are not observed simultaneously, the joint distribution of ( $\varepsilon_{1}$ and $\left.\varepsilon_{0}\right)$ cannot be identified. The assumption is that $p_{0,1}=1$. The estimation is done by Full specification of 
Maximum Likelihood (FML) model. The log likelihood function is defined by (Lokshin and Sajaia, 2004).

$$
\ln L=\sum_{i}\left(\begin{array}{l}
I_{i} W_{i} \mid \ln \left\{F\left(n_{1 i}\right)\right\}+\left\{\int\left(\varepsilon_{1 i} / \sigma_{1}\right) / \sigma_{1}\right\} \\
+\left(1-I_{i}\right) W_{i}\left[\ln \left\{F\left(n_{2 i}\right)+\ln \left\{\int\left(\varepsilon_{2 i} / \sigma_{2}\right)\right\}\right]\right.
\end{array}\right) .
$$

$F($.) is a cumulative normal distribution; $f($.) is a normal density distribution functions, $W_{i}$ is an optional weight for observation $i$ (Araar, 2015).

$$
n_{j i}=\frac{\gamma Z_{i}+\rho_{j} \varepsilon_{j i} / \sigma_{j}}{\sqrt{1-\rho_{j}^{2}}} j=1,2
$$

$\rho_{j}$ is the coefficient of correlation between $\varepsilon_{j}$ and $\mathrm{u}$.

After estimating the parameters of the model, the following conditional and unconditional expectations could be calculated. These expectations are used to determine the treatment effect (Lokshin and Sajaia, 2004)

$$
\left.\begin{array}{c}
E\left(Y_{0 i} \mid x_{0 i}\right)=x_{0 i} \beta_{0} \\
E\left(Y_{1 i} \mid x_{1 i}\right)=x_{1 i} \beta_{01}
\end{array}\right\}
$$

\section{Conditional expectations:}

$$
\begin{aligned}
& E\left(Y_{0 i} \mid I_{i}=1, x_{0 i}\right)=x_{0 i} \beta_{0}+\sigma_{0} p_{0} \\
& E\left(Y_{0 i} \mid I_{i}=1, x_{0 i}\right)=x_{0 i} \beta_{0}-\sigma_{0} p_{0} \\
& E\left(Y_{1 i} \mid I_{i}=1, x_{1 i}\right)=x_{1 i} \beta_{1}+\sigma_{1} p_{1} \\
& E\left(Y_{1 i} \mid I_{i}=1, x_{1 i}\right)=x_{1 i} \beta_{1}-\sigma_{1} p_{1}
\end{aligned}
$$

Estimation of average treatment effects: The ESR can be used to examine the Average effect of Treatment on the Treated (ATT) by comparing the expected outcomes of users using inputs with those not using (counterfactual). The challenge of impact evaluation on quasi and non-experimental studies is to estimate the counterfactual outcome, which is the outcome the users could have earned had they not used the inputs on production. According to Carter and Milon (2005), we compute the ATT in the actual and counterfactual scenarios as;

Users actually using:

$$
\left.\begin{array}{l}
E\left(Q_{0 i} \mid I=1\right)=Z_{i} \alpha_{1}+\sigma_{i} \lambda_{1} \\
E\left(Q_{0 i} \mid I=1\right)=Z_{i} \alpha_{0}+\sigma_{i} \lambda_{0}
\end{array}\right\}
$$

Not-using: (counterfactual)

$$
\left.\begin{array}{c}
E\left(Q_{0 i} \mid I=0\right)=Z_{i} \alpha_{0}+\sigma_{1} \lambda_{0} \\
E\left(Q_{1 i} \mid I=0\right)=Z_{i} \alpha_{1}+\sigma_{1} \lambda_{01}
\end{array}\right\}
$$

The expected outcomes are used to derive unbiased ATT estimates

$$
\begin{aligned}
& A T T=E\left(Q_{1 i} \mid I=1\right)-E\left(Q_{0 i} \mid I=1\right) \\
& =Z_{i}\left(\alpha_{1}-\alpha_{0}\right)+\lambda_{0}\left(\sigma_{1}-\sigma_{0}\right)
\end{aligned}
$$

Users actually using: On the right hand side, the first term represents the expected change in users' mean outcome, if their characteristics had the same return as non-users (same characteristics), $(\lambda)$ is the selection term that captures all potential effects of difference in unobserved variables.

Specification of propensity score matching model: Rosenbaum and Rubin (1983) defined propensity score as the conditional probability of receiving treatment given a vector of observed covariates. Propensity score is a probability of treatment assignment based on observed characteristics. It allows reconstruction of counterfactuals using observational data.

$$
P(x)=\operatorname{Pr}[D=1 \mid X]=E[D \mid X]
$$

Where,

$\mathrm{D}=1$, for treatment

$\mathrm{D}=0$, for control

$\mathrm{X}$ is the vector of observed covariates for the $\mathrm{i}^{\text {th }}$ subject. The propensity score ranges in value from 0 to 1 .

Steps to apply propensity score matching estimate a model of program participation: Pool the example including the two members and non-members and gauge a model of interest (D) as an element everything being equal (vector that is probably going to impact investment). After estimating the model, predicted probabilities corresponding propensity scores are derived using probit, logit, LPM models. Defining the region of common support and balancing propensity score: this region needs to be defined where distributions of the propensity scores for treatment and control group overlap. Some elements from both groups may be excluded if they have a propensity score outside the range.

Matching participants to non-participants and estimating causal effect: different algorithms can be used to assign participants and non-participants based on the estimated propensity scores. This study relies on the nearest neighbour, radius matching, and kernel matching techniques. The following equations estimate the Average Treatment effect on the Treated using different algorithms:

Stratified matching: This technique partitions are the common support into different intervals and provides the impact within each interval. The ATT is estimated by the mean difference in outcome.

$$
A T T=\sum_{q=1}^{0}\left(\frac{\sum_{i} \in I(q) Y_{i}^{\tau}}{N_{q}^{\tau}}-\frac{\sum_{j} \in I(q) Y_{j}^{c}}{N_{q}^{c}}\right) \times \frac{N_{q}^{\tau}}{N^{\tau}}
$$

Where,

$\mathrm{q}$ is the number of blocks with balanced propensity scores, $N_{q}^{T}, N_{q}^{C}=$ Number of cases in the Treatment and control groups for matched block q, $Y_{i}^{T}$, $Y_{j}^{c}=$ Observational outcomes for cases $\mathrm{i}$ and $\mathrm{j}$ matched in the treated and control group q respectively, $N^{T}=$ Total number of cases in the treated group

The nearest neighbour and radius matching: In this matching technique, each treatment unit is matched to the comparison unit with the closest propensity score. In the Radius matching, the outcome of the control group is matched with that of treated group only when the propensity score falls in the predefined radius of the 
treated unit.

$$
A T T=\frac{1}{N^{\tau}}\left(\sum_{i \in \tau} Y_{i}^{\tau}-\frac{1}{N_{i}^{c}} \sum_{j \in c} Y_{j}^{c}\right)
$$

Where

$N^{T}$ Total number of cases in the treated group and $N^{C}$ is a weighting scheme that equals the number of cases in the control group using a specific algorithm.

Kernel matching: Uses the weighted average of all non-participants to build the counterfactual for each participant

$$
\text { ATT }=\frac{1}{N^{\tau}} \sum_{i \in \tau}\left\{Y_{i}^{\tau}-\sum_{i \in c} Y_{j}^{c} K\left(\frac{e_{j}(x)-e_{i}(x)}{h_{n}}\right), \sum_{k \in c} K\left(\frac{e_{k}(x)-e_{i}(x)}{h_{n}}\right)\right\}
$$

Where:

$e_{j}, e_{i}$ denote the propensity score of case $j$ and case $i$ in the control and treatment group respectively. Their difference represents the distance of the propensity scores. $K($.$) is the weight function.$

\section{Variable measurement}

The variables used in the analysis and their theoretical expectations about the sign and magnitude of these variables on the adoption decision of government subsidy assistance cards and impact on farm production and income are discussed below (Table-2). These variables were chosen based on the available literature reviewed.

\begin{tabular}{|c|c|c|c|c|}
\hline Variable Label & Type & $\begin{array}{c}\text { Description/ Household and farmer } \\
\text { characteristics }\end{array}$ & Unit & $\begin{array}{l}\text { Expected } \\
\text { Signs }\end{array}$ \\
\hline \multicolumn{5}{|l|}{ Dependent variables } \\
\hline Rice Production & Continuous & Log of output of rice $\mathrm{kg} / \mathrm{ha}$ & Kilogram/hectare & + \\
\hline Access to ISAC & Dummy & $\begin{array}{l}\text { Dummy }=1 \text { if } \mathrm{HH} \text { had access to ISAC; } 0 \\
\text { otherwise }\end{array}$ & $\mathrm{Yes}=1, \mathrm{No}=0$ & + \\
\hline \multicolumn{5}{|l|}{ Independent variables } \\
\hline $\begin{array}{l}\text { Age of the head of } \\
\text { household }\end{array}$ & Continuous & Age of head of household (years) & years & \pm \\
\hline Gender & Dummy & $\begin{array}{l}\text { Dummy }=1 \text { If household head is male; } 0 \\
\text { otherwise }\end{array}$ & Yes $=1, \mathrm{No}=0$ & \\
\hline Educational status & Continuous & Years of education of the head of household & Year & \pm \\
\hline Marital status & Dummy & $\begin{array}{l}1 \text { if head of household is married; } 0 \text { if single or } \\
\text { widowed }\end{array}$ & Yes $=1, \mathrm{No}=0$ & \pm \\
\hline Household size & Continuous & Number of people in the household & Number & \pm \\
\hline Non-farm income & Dummy & $\begin{array}{l}1 \text { = if household engages in any non-farm } \\
\text { activity }\end{array}$ & $\mathrm{Yes}=1, \mathrm{No}=0$ & \pm \\
\hline Farming experience & Continuous & $\begin{array}{l}\text { Years of household experience in rice } \\
\text { production }\end{array}$ & Year & + \\
\hline Farm size & Continuous & Total land owned by the household in hectares & Hectares & \pm \\
\hline Access to information & Dummy & $\begin{array}{l}1 \text { if household had change information; } 0 \\
\text { otherwise }\end{array}$ & $\mathrm{Yes}=1, \mathrm{No}=0$ & + \\
\hline Access to extension services & Dummy & $\begin{array}{l}1 \text { if household had access to extension; } 0 \\
\text { otherwise }\end{array}$ & $\mathrm{Yes}=1, \mathrm{No}=0$ & + \\
\hline $\begin{array}{l}\text { Access to membership in } \\
\text { agricultural/social } \\
\text { association }\end{array}$ & Dummy & 1 if household belongs to Farmers’ Association & $\mathrm{Yes}=1, \mathrm{No}=0$ & + \\
\hline Access to Technology & Dummy & Farmers access to agricultural technology & Yes $=1, \mathrm{No}=0$ & + \\
\hline Distance to facilities & Continuous & $\begin{array}{l}\text { Distance from farm household agricultural } \\
\text { office / facilities center }\end{array}$ & Kilometers & - \\
\hline Source of income & Continuous & Different sources of income & Number & + \\
\hline Yearly household income & Continuous & Yearly household income & BDT & + \\
\hline Access to social safety net & Dummy & $\begin{array}{l}\text { Access to social safety net ( } 1 \text { if access, } 0 \\
\text { otherwise) }\end{array}$ & Yes $=1, \mathrm{No}=0$ & \pm \\
\hline $\begin{array}{l}\text { Distance to inputs } \\
\text { market }\end{array}$ & Continuous & $\begin{array}{l}\text { Distance from farm household agricultural } \\
\text { office / facilities center }\end{array}$ & Kilometers & - \\
\hline Location_Pangsha Upazila & Dummy & 1 if household is from Pangsha; 0 otherwise & Yes $=1, \mathrm{No}=0$ & + \\
\hline $\begin{array}{l}\text { Location_Kalukhali } \\
\text { Upazila }\end{array}$ & Dummy & 1 if household is from Kalukhali; 0 otherwise & Yes $=1, \mathrm{No}=0$ & + \\
\hline $\begin{array}{l}\text { Location_Baliakandi } \\
\text { Upazila }\end{array}$ & Dummy & 1 if household is from Baliakandi; 0 otherwise & $\mathrm{Yes}=1, \mathrm{No}=0$ & + \\
\hline Location_Rajbari Sadar & Dummy & $\begin{array}{l}1 \text { if household is from Rajbari Sadar; } 0 \\
\text { otherwise }\end{array}$ & $\mathrm{Yes}=1, \mathrm{No}=0$ & + \\
\hline Location_Goalanda Upazila & Dummy & $\begin{array}{l}1 \text { if household is from Golanda Upazila; } 0 \\
\text { otherwise }\end{array}$ & $\mathrm{Yes}=1, \mathrm{No}=0$ & + \\
\hline
\end{tabular}

Table 2. Description of the Variables in the Model

Source: Author Illustration 2020 
Sex of the head of household: It is a dummy variable, 1 if the head of the household is male and 0 otherwise. Male-headed households will have a greater chance of receiving government assistance cards because they are open to fresh information and appear to be risk-takers (Adebiyi and Okunlola, 2013). Due to their reluctant behavior and the higher probability of adopting manure as a proxy for chemical fertilizer, the negative sign was hypothesized while government inputs subsidy assistance cards; whereas positive coefficient was expected for ISAC adoption.

Age of household head: is a continuous variable measured in numbers; as age increases the likelihood of ISAC access by households was expected to decrease; where younger farmers were expected to have access to ISAC, unlike older farmers. In the final test, both for ISAC, the coefficient estimated was negative.

Education: a continuous variable measured in years of schooling; where educated farmers are supposed to acquire, analyze and evaluate information on various agricultural inputs and market opportunities. The coefficient predicted from the final result was positive for both the ISAC adoption.

Plot size: This is a constant calculated hectare feature. Those with big plot sizes could mainly use ISAC to increase productivity. On the other side, those with broad plot sizes will not be forced to implement ISAC, because they could use the following method. Furthermore, large land size holders may not use ISAC for as long as they may use their own inputs. At the other side of the coin, limited land size holders may use ISAC to maximize output and efficiency and thereby fulfill their annual household consumption requirements. The coefficient was also not known or estimated in advance.

Organization affiliation: is a categorical variable; 1 indicates whether a household was a part of farmers' organization or cooperatives, and 0 otherwise. Membership in an association makes it easy for farmers to access inputs at an affordable price relevant for increasing agricultural production and hence farm income (Berihun et al., 2014 and Tewodaj et al., 2009). Farmers can then conveniently follow ISAC on time with an inexpensive price as well as via credit that will be repaid shortly after harvesting. Despite of this, representation in an organization was supposed to have a favorable coefficient when assessing ISAC.

Extension agents' contact: It is a categorical variable representing 1 if households were visited by extension agents and 0 otherwise. Farmers visited by extension agents are exposed for special, fresh, modified knowledge that is used to implement ISAC, thereby raising and doubling agricultural output that could potentially raise farm income (Wondimagegn et al., 2011). Therefore, the contact of the extension agents was expected to have a positive sign or coefficient from the final probit estimation result both for ISAC adoption decision.
Access to agricultural extension services: exposure to farm extension facilities, usage of inoculants and use of better inputs impact the decision of the farmer to compete as a vendor in the crop business. It represents access to structured market knowledge sources which increase the ISAC's probability. Entry to this information decreases transaction costs and business transparency by path. According to Siziba et al. (2011), access to such information reduces perceptions of risk to smallholder farmers and enhances the likelihood of participation in the ISAC.

Access to credit: It is a categorical variable; reflecting 1 whether a household has access to credit, and 0 otherwise. Credit access decreases the liquidity problems that households may face when buying agricultural inputs; and thus paves the way for timely usage of inputs, thereby increasing total production and farm income (Mpawenimana, 2005). Access to credit was also supposed to have a positive symbol, both for ISAC adoption decision, from the final estimate outcome.

Use of irrigation: This is a dummy variable, 1 if farm households were using irrigation practices and water 0 otherwise. When irrigation water existed, farm households will possibly follow ISAC because it is better to consider the availability of water as an assurance for crop loss and subsequent shock. Hence, both for ISAC adoption, positive sign was expected from the final probit estimation result.

Off-farm participation: it is a dummy vector that indicates 1 whether a head of household is interested in off-farm events and 0 otherwise. Participating in off-farm events will address the issue of liquidity when planning to enter the ISAC. Because of this positive coefficient both for ISAC adoption decision is hypothesized in the final estimate test.

Market Distance: It is a constant vector expressed in kilometers; so the greater the journey from the farmers' residence to the nearest market, the improvable would be their ISAC decision to follow them. Therefore, from the final probit estimate test, negative sign was predicted.

Plot distance: it is a continuous variable measured in minutes walking; as the plot is far away from the household, less will be on time plot preparation, weed, harvest and input utilization and then less will be farm income (Minale et al., 2012). Farmers would also be less likely to be at ISAC. As a result, negative coefficient from the final probit calculation test was assumed.

\section{Results and Discussion}

The data analysis has been performed in two steps. In the first section, a description of the socioeconomic characteristics of the sample households comparing adopters and non-adopters is presented. In the second section, we present the econometric results on the role of improved 181 government input subsidy assistance card at the household farm production. 


\subsection{Descriptive Statistics}

This section provides the socioeconomic characteristics of the surveyed households that include age, gender, activity, years of schooling of the household head, the number of years spent on agriculture and source of income. Table 3 presents the mean values of socioeconomic characteristics of the surveyed households.

The results in Table 3 show that the average age and years of education of the heads of household are 47 and six years, respectively. About 53\% of respondents have contact with extension agents. Access to ISAC is a determining factor in choosing adoption strategies, but only about $57 \%$ of small rice farmers have access to ISAC. However, there are clear variations in terms of access to information; for example, about $36 \%$ of farmers who at least adopted a strategy have access to information related to change. About $47 \%$ of the small rice producers in the study area are limited by risk, while $37 \%$ of them have price restrictions and $57 \%$ have quantitative restrictions. The average agricultural experience of farmers in the study area is 15 years.

Table 3. Definitions and Summary Statistics of Variables Used in the Model

\begin{tabular}{|c|c|c|c|}
\hline Variables & Description of variables & Mean & SD \\
\hline \multicolumn{4}{|l|}{ Dependent variables } \\
\hline Rice yield & Log of output of rice $\mathrm{kg} / \mathrm{ha}$ & 7.256 & 8.056 \\
\hline Access to ISAC & Dummy $=1$ if $\mathrm{HH}$ had access to ISAC; 0 otherwise & 0.599 & 0.525 \\
\hline \multicolumn{4}{|l|}{ Independent variables } \\
\hline Gender & Dummy = 1 If household head is male; 0 otherwise & 0.588 & 0.525 \\
\hline Age of the head of household & Age of head of household (years) & 49.644 & 8.054 \\
\hline Marital status & 1 if head of household is married; 0 if single or widowed & 0.840 & 0.420 \\
\hline Educational status & Years of education of the head of household & 6.773 & 5.985 \\
\hline Household size & Number of people in the household & 4.893 & 1.302 \\
\hline Non-farm income & 1 = if household engages in any non-farm activity & 0.567 & 0.525 \\
\hline Farming experience & Years of household experience in rice production & 16.517 & 5.345 \\
\hline Farm size & Total land owned by the household in hectares & 1.825 & 0.793 \\
\hline Access to information & 1 if household had change information; 0 otherwise & 0.378 & 0.504 \\
\hline Access to extension services & 1 if household had access to extension; 0 otherwise & 0.557 & 0.525 \\
\hline $\begin{array}{l}\text { Access to membership in } \\
\text { agricultural/social association }\end{array}$ & 1 if household belongs to Farmers’ Association & 0.567 & 0.525 \\
\hline Access to Technology & Farmers access to agricultural technology & 0.4953 & 0.5023 \\
\hline Distance to facilities & Distance from farm household agricultural office / facilities center & 5.0449 & 2.5998 \\
\hline Source of income & Different sources of income & 2.341 & 0.453 \\
\hline Yearly household income & Yearly household income & 173263 & 76221 \\
\hline Access to social safety net & Access to social safety net ( 1 if access, 0 otherwise) & & \\
\hline Location_Pangsha Upazila & 1 if household is from Pangsha; 0 otherwise & 0.399 & 0.504 \\
\hline Location_Kaluikhali Upazila & 1 if household is from Kaluikhali; 0 otherwise & 0.399 & 0.515 \\
\hline Location_Baliakandi Upazila & 1 if household is from Baliakandi; 0 otherwise & 0.368 & 0.504 \\
\hline Location_Rajbari Sadar & 1 if household is from Rajbari Sadar; 0 otherwise & 0.382 & 0.513 \\
\hline Location_Golanda Upazila & 1 if household is from Golanda Upazila; 0 otherwise & 0.413 & 0.554 \\
\hline
\end{tabular}


Table 4. Determinate of participation in inputs subsidy assistance: Probit Regression-Double Hurdle Model Results

\begin{tabular}{|c|c|c|c|c|}
\hline \multirow{2}{*}{ Variables } & \multicolumn{2}{|c|}{$\begin{array}{c}\text { Probability of participating in the market } \\
\text { (Probit Regression, Hurdle 1) }\end{array}$} & \multicolumn{2}{|c|}{$\begin{array}{l}\text { Intensity of participating in the market } \\
\text { (Truncated Normal Regression, Hurdle 2) }\end{array}$} \\
\hline & Coefficient & $\begin{array}{c}\begin{array}{c}\text { Robust standard } \\
\text { error }\end{array} \\
\end{array}$ & Coefficient & Robust standard error \\
\hline Constant & 1.467 & 0.741 & 29.125 & 10.97 \\
\hline Age of the head of household & $-0.041^{* * *}$ & 0.013 & $-0.541^{* * *}$ & 0.10 \\
\hline Gender & -0.161 & 0.389 & $-10.475^{* * *}$ & 4.84 \\
\hline Educational status & $-0.075^{* *}$ & 0.036 & 0.376 & 0.29 \\
\hline Marital status & -0.349 & 0.380 & -3.083 & 3.71 \\
\hline Household size & $-0.158^{* * *}$ & 0.034 & $0.603^{* * *}$ & 0.22 \\
\hline Non-farm income & 0.001 & 0.010 & 0.099 & 0.10 \\
\hline Farming experience & $1.200^{* * *}$ & 0.426 & 0.174 & 3.91 \\
\hline Farm size & $0.774 * * *$ & 0.284 & 0.652 & 2.49 \\
\hline Yearly household income & 0.001 & 0.000 & $0.003^{* * *}$ & 0.00 \\
\hline Non-farm income & 3.440 & 1.080 & $-10.696^{* *}$ & 4.66 \\
\hline $\begin{array}{l}\text { Access to membership in } \\
\text { agricultural/social association }\end{array}$ & $0.078^{* *}$ & 0.035 & $0.182^{* * *}$ & 0.07 \\
\hline Access to social safety net & 0.035 & 0.282 & -1.807 & 2.81 \\
\hline Access to Technology & $0.964^{* *}$ & 0.377 & $8.249 * * *$ & 3.26 \\
\hline Access to extension services & -0.009 & 0.284 & -2.836 & 2.60 \\
\hline Access to information & $0.526^{*}$ & 0.268 & $0.449 * * *$ & 0.07 \\
\hline Farm production & & & $11.154^{* * *}$ & 4.06 \\
\hline Distance to facilities & & & $-9.133^{* * *}$ & 2.68 \\
\hline $\begin{array}{l}\text { No. of observations }=400 \\
\text { Wald } \chi^{2}(15)=88.83 \\
\text { Prob }>\chi^{2}=0.0000 \\
\text { Log pseudo likelihood }=-417.9167\end{array}$ & & & & \\
\hline
\end{tabular}

\subsection{Determine the Probability of Inclusion in the Grant Assistance Plan for Policy Inputs: Probit Regression-Double Hurdle System}

This command estimates the first and second hurdles of the DHM simultaneously. Diagnostic test for multicollinearity which is a common problem in any regression analysis was conducted based on variance inflation factor (VIF) to identify any potential misspecification problems that may exist in the estimated models. The test shows that the chance model's highest VIFs is 2.09 and that of the sensitivity model is 3.11 . Such values are just below the average value of 10 which is used as a thumb law to imply multicollinearity. That means that in approximate models, multicollinearity is not a concern. Heteroscedasticity is defined with traditional cross-section data as being a specific concern. The established procedure for the correction of heteroscedasticity is to estimate the models using robust standard errors. Therefore, all the models are estimated using robust standard errors to correct for heteroscedasticity.

The results of the determinants of the probability of participating in inputs subsidy programme are displayed in Table 4 . The Wald chi-square value of 88.83 is statistically significant at $1 \%$ indicating that the explanatory variables jointly explain the probability of participating in the ISAC. The decision to participate in the ISAC is significantly determined by age of the household head, year of education, household size, membership in farmers' organization, farm size, annual household income, proportion of off-farm income in total annual household income, output of crops, access to credit and market information. Age is negatively associated with the probability of participation of ISAC. This implies that older farmers have less access to participate in ISAC as compared to younger ones. Randela et al. (2008) observed that younger farmers are expected to be progressive, more receptive to new ideas and to better understand the benefits of agricultural commercialization. Number of years spent in school by the household head is negatively related to the probability to access in ISAC. That is, a higher level of education is associated with a reduction in the probability of participating in the ISAC. This observation contradicts the expectation of Makhura et al. (2001). The results for the determinants of the intensity of market participation are also displayed in Table 4. The intensity of participation in the ISAC is significantly determined by age of the household head, gender of the 
household head, household size, annual household income, proportion of off-farm income in total annual household income, access to technology and information, access to credit, access to social safety net, and access to market information.

\subsection{Determinants of ISAC Participation: FIML Estimates of the ESRM}

This segment introduces the effect measurement of scientific analysis. The ESRM's rho 1 and rho ${ }^{2}$ correlation coefficients are both negative and statistically significant for both the correlation between the ISAC participation equation and the ISAC yield of the participants and non-participants. This indicates that the participants have above-average productivity irrespective of whether or not they are enrolled in the ISAC scheme, but they are better off because they have exposure to ISAC, while non-participants have below-average productivity in any situation but are better off as non-participants. The statistical significance of a probability ratio test for the joint independence of the three equations at 1 percent implies that they should not be estimated separately. The result of the ESRM estimate is in three parts as shown in Table 5, the first part of the ISAC's probit model of access determinants.

Fourteen of the 18 variables used in the probit model was statistically important in affecting ISAC access collection. The probit model results revealed that the socio-economic characteristic variables of farmers such as the age of head of household, marital status, and educational level are statistically significant. In addition, the resources factors, farming expertise, and farm-scale of households are also statistically important in affecting the decision to compete in the ISAC sector. Access to operation, geographic variables and processing costs are other major variables. The second-stage switching regression model estimates for rice productivity (output per hectare) are indicated as participants and non-participants, as presented in Table 5. The marital status, educational status, and farming experience coefficients are negative and are statistically important in influencing rice productivity among farmers who participated in the ISAC sector. The coefficients of marital status, educational level and access to knowledge are in the same vein negative and statistically important in affecting non-participant rice development. The findings indicate that a unit improvement in the marital status of rice farmers, the amount of years spent in education, and access to knowledge would result in a $9.3 \%$ decrease in rice production, $0.8 \%$, and $6.1 \%$ respectively. The conventional nature of some experienced farmers could be attributed to a plausible explanation for the negative relationship between farming experience and rice productivity. Some farmers are so satisfied with their traditional farming method that they find it hard to switch to new farming practices, thus reducing the efficiency of production. This result is in line with Danso-Abbeam and Baiyegunhi, (2017) who have noticed a detrimental association between the knowledge of farming and technological effectiveness. The number of years spent in school is negatively signed with rice productivity could also be traced to the fact that the number of years in formal education may not necessarily increase one's productive efficiency as compared to the level of knowledge in its environment of production. The result is compatible with the studies of Binam et al. (2008) and Onumah et al. (2013), who have estimated schooling as a declining productivity feature. In explaining variations in rice productivity, the coefficients of farm size and household size are both positive and statistically significant. It is in accordance with both the Rahman (2009) and Benin et al. (2004) which have demonstrated that farm-scale positively affects crop productivity. Such results also corroborate the results of Tijani et al., (2006); Abdallah (2016), which has found a favorable association between farm size and yield. Rice production is therefore projected to increase dramatically when rice farmers have ample land to grow. Rice development is greatly affected by family size. Benin et al. (2004) noted the significantly positive influence for cereal crop diversity on farms in Bangladesh by male members within the family. Table 5 findings revealed that an improvement in both the size of the farm and the size of the family would improve the production of rice by $0.5 \%$ and $1.1 \%$ respectively. The results of this study show that the household size coefficient has a positive relation to the productivity of the rice. This indicates that the size of the household has a positive influence on the rice farmers' output in the study area. The result is that household members make a substantial commitment to supplying family labor, contributing to an improvement in rice yield (Danso-Abbeam and Baiyegunhi, 2017). This is in accordance with the results of Okorie et al. (2011), who observed that farmers with higher household size received higher yield owing to the availability of family labour. This lowers the cost of production because the cost of family labor, particularly in developed countries, is not often included in the cost of production. 
Table 5. FIML Estimates of the Endogenous Switching Regression Model

\begin{tabular}{|c|c|c|c|c|c|c|}
\hline \multirow{3}{*}{ Variables } & \multirow{2}{*}{\multicolumn{2}{|c|}{$\begin{array}{l}\text { Participation to Govt. } \\
\text { input subsidy assistance } \\
\text { card }\end{array}$}} & \multicolumn{4}{|c|}{ Farm production } \\
\hline & & & \multicolumn{2}{|c|}{$\begin{array}{l}\text { Participation to Govt. input } \\
\text { subsidy assistance card }\end{array}$} & \multicolumn{2}{|c|}{$\begin{array}{l}\text { Non-participation to Govt. } \\
\text { input subsidy assistance card }\end{array}$} \\
\hline & Coef. & Std. Err. & Coef. & Std. Err. & Coef. & Std. Err. \\
\hline Ln of rice production (Kg/ha) & & & 7.971 & 6.707 & 7.601 & 6.457 \\
\hline Age & $0.034^{*}$ & 0.018 & -0.001 & 0.001 & 0.000 & 0.001 \\
\hline Gender & 0.208 & 0.232 & 0.005 & 0.012 & 0.005 & 0.012 \\
\hline Marital status & $-1.388 * * *$ & 0.357 & $-0.089 *$ & 0.015 & $-0.099 * * *$ & 0.016 \\
\hline Educational status & $0.062 * *$ & 0.026 & $-0.009^{* * *}$ & 0.001 & $-0.008^{* * *}$ & 0.001 \\
\hline Farming experience & $0.049 *$ & 0.026 & $-0.003 * * *$ & 0.001 & -0.001 & 0.001 \\
\hline Household size & 0.030 & 0.083 & $0.012 * * *$ & 0.004 & -0.006 & 0.004 \\
\hline Farm size & $-0.076^{*}$ & 0.044 & $0.005 * * *$ & 0.002 & 0.001 & 0.002 \\
\hline Non-farm income & 1.132 & 1.037 & -0.057 & 0.041 & -0.005 & 0.047 \\
\hline Access to extension services & $-1.869 * *$ & 0.941 & 0.054 & 0.041 & 0.011 & 0.047 \\
\hline Access to information & $0.840 * * *$ & 0.280 & -0.008 & 0.015 & $-0.065^{* * *}$ & 0.019 \\
\hline Access to social safety net & -0.285 & $0.48)$ & -0.167 & 0.147 & -0.122 & 0.091 \\
\hline Yearly household farm income & $1.490 * * *$ & 1.610 & $1.110^{* * *}$ & $0.372 * * *$ & 2.173 & 0.451 \\
\hline Access to Technology & 0.4953 & 0.5023 & 0.040 & 0.136 & 0.012 & 0.089 \\
\hline Location_Pangsha Upazila & $-0.597 * *$ & 0.273 & 0.019 & 0.016 & -0.016 & 0.014 \\
\hline Location_Kaluikhali Upazila & $0.454^{*}$ & 0.259 & -0.008 & 0.016 & -0.002 & 0.014 \\
\hline Location_Baliakandi Upazila & $-0.959 * *$ & 0.382 & -0.024 & 0.017 & -0.020 & 0.017 \\
\hline Location_Rajbari Sadar & -0.669 & 0.240 & -0.081 & 0.094 & -0.002 & 0.063 \\
\hline Location_Golanda & -0.285 & 0.482 & -0.167 & 0.147 & -0.122 & -0.091 \\
\hline Distance to inputs market & $-5.887 * *$ & 2.575 & 0.026 & 0.120 & 0.017 & 0.125 \\
\hline Access to Credit & $-0.053^{* * *}$ & 0.017 & 0.000 & 0.001 & 0.000 & 0.001 \\
\hline Constant & 166.009 & 71.648 & 7.248 & 3.335 & 7.571 & 3.483 \\
\hline Distance to facilities & $0.042^{* *}$ & & & & & \\
\hline Source of income & $-1.862 * * *$ & & & & & \\
\hline $\begin{array}{c}\text { Access to membership in } \\
\text { agricultural/social association }\end{array}$ & 0.984 & & & & & \\
\hline /lns1 & $-2.835 * * *$ & & & & & \\
\hline /lns2 & $-2.717 * * *$ & & & & & \\
\hline$/ \mathrm{r} 1$ & $-1.099 * * *$ & & & & & \\
\hline$/ \mathrm{r} 2$ & $-1.195^{* * *}$ & & & & & \\
\hline sigma_1 & $0.070 * * *$ & & & & & \\
\hline sigma_2 & $0.079 * * *$ & & & & & \\
\hline rho_1 & $-0.820 * * *$ & & & & & \\
\hline rho_2 & $-0.855 * * *$ & & & & & \\
\hline
\end{tabular}

Note: $* * *, * *$, and $*$ represent significance level at $1 \%, 5 \%$, and $10 \%$, respectively.

Sources: Field survey data 2020 
Table 6. Average Treatment Effects on the treated using ESR

\begin{tabular}{cccccc}
\hline & \multicolumn{2}{c}{ Participants } & \multicolumn{2}{c}{ Non-participants } & \multirow{2}{*}{ Treatment Effects } \\
\cline { 2 - 5 } & Mean & Std. Dev. & Mean & Std. Dev & \\
\hline Users of ISAC & 7.0687 & 0.4486 & 6.336 & 0.4486 & ATT $=0.7327^{* * *}$ \\
\hline Non Users of ISAC & 6.8924 & 0.4402 & 6.2299 & 0.3865 & ATU $=0.6625^{* * *}$ \\
\hline
\end{tabular}

Source: Author illustration 2020

Table 7. Average Treatment Effect on the Treated using Propensity Score matching

\begin{tabular}{ccccc}
\hline Testing Matching method & Participants & Non-participants & ATT & Std. Err. \\
\hline Kernel Matching method & 181 & 219 & 0.502 & 0.121 \\
Radius Matching method & 103 & 211 & 0.430 & 0.097 \\
Nearest Neighbor Matching method & 180 & 115 & 0.609 & 0.158 \\
\hline
\end{tabular}

Source: Author illustration 2020

\subsection{Effect of Inputs on Productivity}

The influence of inputs on output can be determined by adding in the resulting equation the values of the variables for each farmer. It will require the expected output to be measured for every category. Table 6 indicates the average treatment impact dependent on conditional assumptions on the treated individual.

The conditional input effect measures differences in output level within input users with and without the use of inputs. The assumption is that the coefficients obtained in the switching regression for users would apply to those who do not use, if they used inputs and vice versa. Results indicate that the average impact on inputs is calculated to be positive indicates that users' inputs experience preferential benefits on non-observable attributes over non-users and have a positive effect on productivity. This means that even in the absence of inputs, users would still do better than non-users; therefore, positive selection in regime 1 and negative selection in regime 0 are available. Results in Table 6 suggest that gains from the usage of inputs provided from non-users are smaller than profits for those who already use it. The effect of the conditional inputs is estimated positive. This result is derived by calculating the disparity between the rice production rates of consumers with inputs and non-users, which implies that rice efficiency with inputs is higher than the counterfactual situation where there are inputs. The difference between the effect of average inputs and the effect of conditional inputs may be interpreted as the unobservable productivity attributes of those who use inputs.

\subsection{Propensity Score Matching}

Propensity score matching was used to compute the ATT. Results drawn from three different algorithms suggest that government input subsidy assistance card inputs have a positive effect on productivity (Table 7).

Similar to those obtained using Endogenous Switching regression, these findings are more robust in ESR however.
The idea that current non-users would not produce as much from the use of inputs as current users is strongly supported. The table above shows the ATT drawn from the propensity score by matching methods for the kernel, radius, and NN. ATT's lowest value was obtained by the Radius Matching process, and the maximum was obtained by matching the Nearest Neighbor, but lower than the ATT obtained using ESR.

\section{Conclusions and Recommendations}

The goal of this study was to assess the impact of inputs on rice production and farm incomes in the district of Rajbari under seven million programmes. The results of the analysis of the surveyed households' socioeconomic characteristics showed that the majority of farmers (90 percent) fell below the most economically active period of 20 to 50 years and just 10 percent are over 50 years old. As far as the education level is concerned $41 \%$ of the respondents have spent less than 5 years in the school and only $8 \%$ attended secondary school achieved first degree equivalent to 10 years of schooling. As regards gender, the analysis found that $63 \%$ of the households surveyed were headed by males while $37 \%$ were female households.

Our research showed that input subsidy consumers had slightly more years of education, more years of practice, more fertilizer usage, higher rice production but less land cultivation than non-users. Farm size and product demand gaps have been shown to be statistically negligible. As for objective one, inputs have a positive and statistically significant effect on rice productivity. The ESR was conducted to find the factors influencing the usage of inputs and the average treatment effect. The findings obtained show that the extension services were statistically significant with a favorable impact on the inclusion of subsidies in inputs. Other important variables but with negative effects were distance to the input market and source of income. However, subsidy inputs allowed users to use more inputs, thus producing more output. Extension 
services and level of education were significant and had a positive effect on rice productivity for non-users but insignificant for those who actually used it, distance to the input market had a negative effect on those who did not use it but it also turned insignificant to users. The average treatment effect suggests that apart from inputs use, users enjoy the differential benefits of non-observable attributes over non-users that add to the rice productivity's positive influence.

In terms of the second objective, it was found that the farm income of those who used inputs under the program was higher than those not using as a result of more input use and a higher level of the rice output, this is because inputs enable farmers to adopt new technologies which in turn will change the levels of productivity and generate more farm income. With respect to the second objective, it was observed that the farm income of those who used inputs under the system was higher than that of those who did not use as a consequence of increased usage of inputs and higher rice productivity on rates, this is because inputs allow farmers to implement new technology that, in effect, would improve productivity levels and produce more agricultural income. The results also revealed that inputs subsidy has a positive and significant effect on rice productivity. Therefore, this study recommends that the authority concern in the allocation of inputs should continue and even increase the allocation amount to enhance the farmers' production capacity in the Rajbari district. These findings indicate that implementing the ISAC program along with strong extension service could help in this direction as it is a creative participatory and interactive model approach to improve productivity for rice farmers.

\section{Contribution of the Research}

This study is expected to contribute to the literature on boosting farm productivity in Bangladesh as well as in developing countries for government input subsidy assistance will have a significant effect on productivity enhancement.

\section{Deposition of Data}

The authors may access the details and supplementary records of the results of this analysis upon request.

\section{Dissemination Statement}

The authors had reported no potential conflict of interest.

\section{REFERENCES}

[1] Abdulai, A., Huffman, W. (2014). The Adoption and Impact of Soil and Water Conservation Technology: An Endogenous Switching Regression Application. Land Econ. Vol.90 (1), PP: 26-43.

[2] Adebiyi, S., Okunlola, J.O. (2013). Factors Affecting Adoption of Cocoa Farm Rehabilitation Techniques in Oyo State of Nigeria, World Journal of Agricultural Sciences, Vol.9 (3), PP: 258-265, DOI: 10.5829/idosi.wjas.2013.9.3.1 736

[3] Alene, A. D., and Manyong, V. M. (2007). The Effects of Education on Agricultural Productivity Under Traditional and Improved Technology in Northern Nigeria: An Endogenous Switching Regression Analysis, Springer Empirical Economics, Vol.32, PP: 141-159.

[4] DOI 10.1007/s00181-006-0076-3

[5] Alston, J. M. and James, J.S (2002). The Incidence Of Agricultural Policy, Gardner and G.C. Rausser (eds.) Handbook of Agricultural Economics, Elsevier, Vol. 2B (1).PP:689-1,749

[6] Amare, M., Asfaw, S., Shiferaw, B. (2012). Welfare Impacts of Maize Pigeonpea Intensification in Tanzania. Agricultural Economics. Vol. 43(1), PP: 27-43.

[7] Asfaw, S., Shiferaw, B., Simtowe, F., Lipper, L. (2012). Impact of Modern Agricultural Technologies on Smallholder Welfare: Evidence from Tanzania and Ethiopia. Food Policy, Vol.37(3), PP: 283-295.

[8] Asfaw, Solomon and Shiferaw, Bekele (2017). Agricultural Technology Adoption and Rural Poverty: Application of an Endogenous Switching Regression for Selected East African Countries, Poster presented at the Joint 3rd African Association of Agricultural Economists (AAAE) and 48th Agricultural Economists Association of South Africa (AEASA) Conference, Cape Town, South Africa, September 19-23, 2010

[9] Berihun K. H., Bihon K. A., Kibrom A. W. (2014). Adoption and Impact of Agricultural Technologies on Farm Income: Evidence from Southern Tigray, Northern Ethiopia, International Journal of Food and Agricultural Economics, Vol. 2(4), PP: 91-106

[10] Binam, J. N., Gockowski. J., Nkamleu.G.B. (2008). Technical Efficiency and Productivity Potential of Cocoa Farmers in West African Countries. The Developing Economies, Vol,46(3), PP: 242-263

[11] Burke WJ (2009). Fitting and Interpreting Cragg's Tobit Alternative Using Stata. Stata J. Vol. 9(4), PP: 584-592.

[12] Buttari, J. J. (1995). Subsidized Inputs Programs: The theory, the Record, the Alternatives. USAID Evaluation Special Study.

[13] Carter, D. W., \& Milon, J. W.(2005). Price Knowledge in Household Demand for Utility Services. Land Economics, Vol. 81(2), PP: 265-283.

[14] Chamberlin J, Diao X, Kolavalli S, Breisinger C (2007). Smallholder Agriculture in Ghana. International Food Policy Research Institute (IFPRI). Ghana Strategy Support Program. IFPRI Discussion P. 3.

[15] Ciaian, P. and Swinnen, J.F.M. (2009). Credit Market Imperfections and the Distribution of Policy Rents, American Journal of Agricultural Economics, Vol. 91, PP: 
1124-1139.

[16] Ciaian, P., Pokrivcak, J. and Szegenyova, K. (2012). Do Agricultural Subsidies Crowd Out or Stimulate rural Credit Market Institutions? The case of EU Common Agricultural Policy, European Integration Online Papers, Vol. 16, PP: 117

[17] Dalango D and Tadesse (2019). Determinants of Smallholder Teff Farmer's Chemical Fertilizer Technology Adoption in Southern Ethiopia, in Case of Gena District in Dawro Zone (Hechman Two-Stage Model), Journal of Perspectives on Financing and Regional Development, Vol. 7(2), PP:111-125

[18] Danso-Abbeam, G.m., Baiyegunhi, L.J. S. (2017). Adoption of Agrochemical Management Practices among Smallholder Cocoa Farmers in Ghana, African Journal of Science, Technology, Innovation and Development, Vol. 9(6), PP: 717-728

[19] Dorward, A. (2009). Rethinking Agricultural Input Subsidy Programmes in a Changing World. London: SOAS.

[20] Dorward, A., Chirwa, E. and Slater, R. (2010). Evaluation of the Agricultural Input Subsidy Programme, Malawi: Report on Programme Implementation, Report presented to the Government of Malawi and DFID, Lilongwe, Malawi: Malawi Government and DFID (Malawi).

[21] Dorward, A., Chirwa, E., Boughton, D., Crawford, E., Jayne, T., Slater, R. (2010). Towards Smart Subsidies in Agriculture? Lessons from Recent Experience in Malawi, London: ODI.

[22] Duso, T. (2005). Lobbying and Regulation in a Political Economy: Evidence from the US Cellular Industry. Public Choice, Vol. 122(3\&4), PP: 251-276.

[23] Ekise, I. E., Nahayo, A., Mirukiro, J. d., Nsengiyumva, B. (2013). Analysis of the Impact of Agricultural Input Subsidies Voucher Programme on the Livelihoods of Small Scale Rice Producers in Kirehe District, Eastern Rwanda. New York Science Journal, Vol. 6(9), PP: 32-44.

[24] Hennessy, D. A. (1998). The Production Effects of Agricultural Income Support Policies under Uncertainty. American Journal of Agricultural Economics, Vol. 80 (1), PP: 46-57

[25] Hennessy, D. A. (1998). The Production Effects of Agricultural Income Support Polices Under Uncer Tainty, American Journal of Agricultural Economics, Vol. 80, PP: 46-57.

[26] Hermes, N., \& Lensink, R. (2007). The Empirics of Microfinance: What Do We Know? The Economic Journal, PP: 117-517

[27] Kassie, M., Teklewold, H., Marenya, P., Jaleta, M., Erenstein, O. (2015). Production Risks and Food Security under Alternative Technology Choices in Malawi: Application of a Multinomial Endogenous Switching Regression. Journal of Agricultural Economics, Vol. 66(3), PP: 640-659.

[28] Key N, Sadoulet E, de Janvry A (2000). Transactions Costs and Agricultural Household Supply Response. American Journal of Agricultural Economics, Vol. 82(1), PP: 245-259.

[29] Kothari (2004). Research Methodology, Methods and
Technique, Second Revised Edition. New Age International Publishers

[30] Lokshin M, Sajaia Z (2004). Maximum Likelihood Estimation of Endogenous Switching Regression Models, Stata Journal Vol.4 (3), PP: 282-289

[31] Maddala, G.S., Nelson, F.D. (1983). Switching Regression Models with Exogenous and Endogenous Switching, in Proceedings of the American Statistical Association, Business and Economics Section, Vol.(5), PP: 423-426.

[32] Makhura M.N, Kirsten J, Delgado C. (2001). Transaction Costs and Smallholder Participation in the Rice Market in the Northern Province of South Africa. In Seventh Eastern and Southern Africa Regional Rice Conference, Pretoria, South Africa, 11-15 February PP: 463-467.

[33] Malikov E. and Kumbhakar S.C (2014). A Generalized Panel Data Switching Regression Model, Economics Letters, Forthcoming, State University of New York (SUNY) at Binghamton Department of Economics, Online available https://papers.ssrn.com/sol3/papers.cfm?Abstract_id=24570 09

[34] Menale,K., Moti, J., Bekele. S., Mmbando, F., Muricho, G. (2012). Plot and Household Level Determinants of Sustainable Agricultural Practices in Rural Tanzania, Environment for Development Discussion Paper Series EFD DP 12-02

[35] Mpawenimana, J. (2005). Analysis of Socio-Economic Factors Affecting the Production of Bananas in Rwanda: A Case Study of Kanama District. University of Nairobi

[36] Okorie, F. C., Okeke, I., Nnaji, A., Chibo, C. Pat Mbano, E. (2012). Evidence of Climate Variability in Imo State of Southeastern Nigeria, Journal of Earth Science and Engineering, Vol.2(9), PP: 544-553.

[37] Olwande J, Mathenge M (2012). Market Participation among Poor Rural Households in Kenya. In paper presented at the international association of agricultural economists triennial conference, Brazil. (18-24 August)

[38] Onumah, J. A., Al-Hassan, R. M. Onumah, E.E. (2013). Productivity and Technical Efficiency of Cocoa Production in Eastern Ghana. Journal of Economics and Sustainable Development, Vo. 4(4), PP: 106-117

[39] Rahman, S. u., Hussain, A., Taqui, M. (2014). Impact of Agricultural Inputs on Agricultural Productivity in Pakistan: An empirical analysis. International Journal of Advanced Research in Management and Social Sciences, Vol. 3(4), PP: 125-139.

[40] Randela R, Alemu ZG, Groenewald J.A (2008). Factors Enhancing Market Participation by Small-Scale Cotton Farmers. Agrekon, Vol.47(4), PP:451-469.http://dx.doi.org/ 10.1080/03031853.2008. 9523810

[41] Rizov, M. and Walsh, P. (2011). Is there a Rural-Urban Divide? Location and Productivity of UK Manufacturing, Regional Studies, Vol. 45, PP: 641-656.

[42] Rizov, M., J. Pokrivcak., P. Ciaian. (2013). CAP Subsidies and Productivity of the EU Farms. Journal of Agricultural Economics Vol. 64 (3), PP: 537-57.

[43] Rosenbaum and Rubin (1983). The Central Role of the Propensity Score in Observational Studies for Causal Effects, 
Biometrika, Vol. 70(1), PP: 41-55

[44] Sheahan, M., Black, R., Jayne, T. S. (2013). Are Kenyan Farmers Under-utilizing fertilizer? Implications for Input Intensification Strategies and Research, Food Policy, Vol.41, PP: 39-52.

[45] Sheahan, Megan, and Christopher B. Barrett (2017). Ten Striking Facts about Agricultural Input use in Sub-Saharan Africa, Food Policy, Vol. 67, PP:12-25, DOI:10.1016/j.foodpol.2016.09.010

[46] Siziba S, Kefasi N, Diagne A, Fatunbi A.O., Adekunle A.A. (2011). Determinants of Cereal Market Participation by sub-Saharan Africa Smallholder farmer, Learning Publics, Journal Agriculture Environmental Studies Vo. 2(1), PP:180-193

[47] Tewodaj, M., Cohen, M.J., Birner, R., Mamusha, L., Randriamamonjy, J., Fanaye, T., Zelekawork, P. (2009). Agricultural Extension in Ethiopia through a Gender and
Governance Lens.Ethiopia Strategy Support Program 2 (ESSP2) Discussion Paper No. ESSP2 007

[48] Tijani, A. A., Alimi, T., Adesiyan, A. T. (2006). Profit Efficiency among Nigerian Poultry Egg Farmers: A Case Study of Aiyedoto Farm Settlement, Nigeria, Research Journal of Agricultural Biological Sciences, Vol. 2(6), PP: 256-261

[49] Wondimagegn Tesfaye and Nyasha Tirivayi (2016). The Effect of Improved Storage Innovations on Food Security and Welfare in Ethiopia Wondimagegn Tesfaye and Nyasha Tirivayi, UNU-MERIT Working Papers intend to disseminate preliminary results of research file://C:/Users/MM\%20Computer/Downloads/wp2016-063 .pdf

[50] Wondimagegn, M., Bekabil, F., Jema,H.(2011). Pattern, Trend and Determinants of Crop Diversification: Empirical Evidence from Smallholders in Eastern Ethiopia. Journal of Economics and Sustainable Development, Vol. 2(8). 